University of Nebraska - Lincoln

DigitalCommons@University of Nebraska - Lincoln

Faculty Publications, College of Journalism \& Journalism and Mass Communications, College Mass Communications

2012

\title{
The Effect of Advertising-Focused, Short-Term Study Abroad Programs on Students' Worldviews
}

Frauke Hachtmann

University of Nebraska - Lincoln, fhachtmann1@unl.edu

Follow this and additional works at: https://digitalcommons.unl.edu/journalismfacpub

Part of the International and Intercultural Communication Commons, International Business Commons, Mass Communication Commons, and the Public Relations and Advertising Commons

Hachtmann, Frauke, "The Effect of Advertising-Focused, Short-Term Study Abroad Programs on Students' Worldviews" (2012). Faculty Publications, College of Journalism \& Mass Communications. 68. https://digitalcommons.unl.edu/journalismfacpub/68

This Article is brought to you for free and open access by the Journalism and Mass Communications, College of at DigitalCommons@University of Nebraska - Lincoln. It has been accepted for inclusion in Faculty Publications, College of Journalism \& Mass Communications by an authorized administrator of DigitalCommons@University of Nebraska Lincoln. 


\title{
The Effect of Advertising-Focused, Short-Term Study Abroad Programs on Students' Worldviews
}

\author{
Frauke Hachtmann, University of Nebraska-Lincoln
}

\begin{abstract}
Global employers in the advertising industry are increasingly interested in hiring students with intercultural communication skills and cultural experience. While the benefits of long-term study abroad programs are well documented, this study focuses on advertising-specific, short-term study abroad programs. The purpose was to explore the effectiveness of such programs on students'worldviews using a mixed methods design. The results show that students displayed lower levels of ethnocentrism after participating in short-term, advertising-focused study abroad programs. In addition, five qualitative themes emerged: an awareness of and appreciation for the out-group, an increased awareness of the in-group, the importance of communication, a positive effect on professional goals, and opportunities for personal growth and inspiration to explore cultures in more depth.
\end{abstract}

In response to a globalized world with increasingly open borders, institutions of higher education have focused on "internationalizing" their curricula for many years. In particular, advertising practitioners and educators recognized that advertising students needed to be prepared to work in international markets (Miracle, 2008; Dunn, 1994). Despite the recent global economic recession, the global advertising industry has a total value of $\$ 98$ billion. This value is predicted to increase to $\$ 120.7$ billion by 2014 , which is a 23.2 percent increase in only five years (Datamonitor, 2010). Research shows that global employers in the advertising industry are particularly interested in hiring students who have international advertising skills (Rose \& Miller, 1993; Heiman, 2001) as well as advertising and cultural experience (Lee, Chen \& Katz, 1997). The dominance of the American advertising industry in the global marketplace is reflected by the many advertising curricula in higher education across the country that are preparing their students to compete in a globalized world. The Accrediting Council on Education in Journalism and Mass Communications (ACEJMC) also recognizes this need, requiring those programs that seek accreditation to "demonstrate an understanding of the diversity of peoples and cultures and of the significance and impact of mass communications in a global society" (Accrediting Council on Education in Journalism and Mass Communications, 2010, p. 42). In addition, programs can seek accreditation by the International Advertising Association (IAA), whose purpose is to ensure high quality teaching and content acceptable in the global communications community (International Advertising Association, 2011).

One way to internationalize the curriculum and to give students an opportunity to learn and demonstrate their ability to exchange verbal and non-verbal messages with individuals from other cultures, also known as "intercultural communication skills" (Neuliep, 2006, p. 38), is to offer advertising-specific, short-term study abroad programs (Ganahl \& Rose, 2000). The level of one's ethnocentrism, which can be defined as "the tendency to place one's own group (cultural, ethnic or religious) in a position of centrality and worth, and to create negative attitudes and behaviors toward other groups" (Neuliep, 2006, p. 38), can be an indicator of a person's intercultural communication skills as cultural competence and ethnocentrism are inversely related (Capell, Dean \& Veenstra, 2008). Research shows that short-term study abroad programs can have a positive effect on the overall development of students' cross-cultural sensitivity (Anderson, Lawton, 
Rexeisen \& Hubbard, 2006). In addition, several studies indicate that study abroad programs affect students' worldviews as measured by their level of ethnocentrism both positively and negatively (Pedersen, 2010; Jackson, 2008; Kambutu \& Nganga, 2008). However, no studies currently exist that investigate the effect of short-term study abroad programs that have a clearly defined advertising focus. Therefore, the purpose of this study was to explore the effectiveness of advertising-focused, short-term study abroad programs on students' worldviews.

\section{Literature Review}

\section{History and Growth of Study Abroad}

Since the 1970s, study abroad experiences have become a common theme among college students in the United States. However, what started out as a general education model that focused on sending mostly female students to Western Europe for language and cultural training has evolved dramatically over the past 40 years as the demand for cross-culturally competent professionals in an increasingly globalized world grew quickly. As a result, there is no "typical" study abroad experience in the twenty-first century (Burn, 2003).

As English has become the lingua franca of the world, the focus of study abroad experiences has diversified tremendously. Two main reasons contributed to the diversity of study abroad programs. The first was a focus on enhancing students' professional qualification for future careers such as international internships and jobs. The second was a growing appreciation among employers and faculty of cross-cultural skills but not necessarily foreign language competence. Those two reasons also contributed to the increasing popularity of short-term study abroad programs and a decrease in long-term study abroad experiences. For example, in 1985,18 percent of U.S. college students spent more than one month abroad while in 1995 only 10 percent did so (Burn, 2003).

Burn (2003) distinguishes between two main types of study abroad programs. The first type of program involves partnerships with institutions abroad and prepares students for the experience, but then lets the partner institution carry out the program itself and teach the courses. The second type of program, which is gaining popularity, is more focused on the needs of individual students. These are special academic short-term programs that are facultyled and address specific interests of students. Other characteristics of twenty-first century study abroad programs include experiential learning and immersion in the host culture via participation in community service. In addition, faculty increasingly encourage students to participate in independent study as well as interdisciplinary and multi-disciplinary study (Burn, 2003).

Although a growing number of American students appear to be interested in study abroad programs, less than two percent of college students actually travel abroad for academic reasons. Among the reasons for this relatively small percentage are "security concerns, high cost, academic demands that accommodate neither study abroad nor other international learning experiences, and lack of encouragement by faculty and advisers" (Williamson, 2010, p. 1). One obstacle for many students is the high cost that can be associated with study abroad programs. Successful programs are transparent about their financial model and actively work toward minimizing costs. Universities can battle most of these obstacles, which they hope will contribute to more American students choosing to experience a different culture in an academic context.

Williamson identified seven characteristics of "study-abroad-friendly" universities. Study abroad programs are more likely to be successful when administrators and faculty members work together as "administrators have the power of finance, while professors have the power of influence" (Williamson, 2010, p. 2 ). Universities should also offer a variety of different program options that are supported by academic departments. In addition, successful study abroad programs prepare adequately for risk by using a rigorous screening/application process that involves key offices on campus such as judicial affairs, health services, disability services and psychological counseling. They should promote health and safety throughout the international experience and provide health insurance, crisis-management protocols, training and orientation.

Williamson (2010) furthermore suggests that every department should try to "connect international learning experiences to academic needs" (p. 3) by incorporating study abroad options into the advising process and thereby shifting study abroad experiences from extracurricular experiences to academic ones. She also recommends that approved study abroad courses count as academic credit toward a student's degree completion. Finally, she suggests that universities educate students who are about to study abroad about their carbon footprint, thereby increasing their awareness about environmentally friendly processes (Williamson, 2010). 


\section{Advertising-Focused Study Abroad Programs}

While international students often come to the United States to learn about advertising, American students learn about international markets mostly from within the United States (Dunn, 1994). Many advertising programs in the United States offer one or more international advertising courses or embed the global competency in other courses. Other ways to internationalize the advertising curriculum include requiring a minor that relates to intercultural communication, offering team-taught interdisciplinary courses related to intercultural communication, offering interdisciplinary degrees or certificate programs, encouraging students to develop a geographic area of interest that could be explored through special topics courses or off-campus learning opportunities, devising student projects that involve student teams from other countries and offering advertising-specific faculty-led study abroad courses (Ganahl \& Rose, 2000). Ganahl and Rose (2000) were among the first to call for study abroad experiences to offer students an opportunity to learn and apply intercultural communication skills. They advocate for faculty to develop short-term study abroad courses for students to get a glimpse into another culture. This recommendation is in line with current trends in study abroad experiences which are characterized by the widening of study abroad destinations and shortening of time spent abroad (Burn, 2003).

An increasing number of universities and colleges are starting to offer advertising- and public relations-focused short-term study abroad courses all across the globe. However, there is a shortage of studies that investigate how effective these types of programs are in terms of increasing students' intercultural communication skills while decreasing their level of ethnocentrism. For example, Dickerson (2005) described, in detail, an international public relations course offered by George Mason University, which is taught in London, England. Dickerson focused on a detailed description of the program but did not intend to measure the effectiveness of this type of study abroad experience. Using a different approach, Steeves (2006) describes how students can experience hands-on global communication by participating in a short-term study abroad program in combination with an internship program in Ghana, West Africa. By combining formal instruction with hands-on opportunities to practice newly learned skills, students were able to seamlessly move from theory to practice. Despite acculturation challenges early on, student reflections and other assignments showed how the challenges can be overcome and result in a sense of personal and professional growth. No studies currently exist that measure students' intercultural communication skills gained as a result of having participated in an advertising or public relations-themed shortterm study abroad course.

\section{Intercultural Communication Skills and Ethnocentrism}

An increasingly globalized world presents tremendous opportunities and challenges for today's students including global competency and effective intercultural communication skills (Jackson, 2010). Intercultural literacy includes the process of questioning one's own conventions and values, experiencing an out-group situation, reflecting on the interactions among different groups and analyzing one's intercultural experiences and acting on them (Alred, Byram \& Fleming, 2006). Interculturality is about experiencing differences between in-groups (individuals who share a common cultural background) and outgroups (individuals who are seen as outsiders by members of the in-group). According to intergroup contact theory (Allport, 1954) faceto-face interaction between different groups of people will decrease prejudice among members of both groups as long as each group has equal status and common goals, is focused on intergroup cooperation instead of competition and has encouragement from "higher authorities" (Jackson, 2010, p. 26). However, research has shown that when these conditions are not met, the level of ethnocentrism among students returning home from study abroad experiences may actually increase (Jackson, 2008) as negative experiences can elevate one's identity with his/her in-group.

A primary goal of study abroad programs is to develop global competence among program participants. Many different models define the term "global competence." For the purpose of this study, it can be defined as having sufficient substantive knowledge, perceptual understanding and intercultural communication skills to function in a globalized world (Olsen \& Kroeger, 2001). Taking the interaction between in-groups and out-groups into account, characteristics of global competence include the following: a) general knowledge of the in-group, b) general knowledge of the outgroup, c) fluency in a different language, d) cross-cultural empathy, e) openness and cognitive flexibility, f) tolerance or ambiguity, perceptual acuity and attentiveness to nonverbal messages and g) awareness of issues 
facing the global community (Donatelli, Yngve, Miller, \& Ellis, 2005).

Bennett (1993) created the Developmental Model of Intercultural Sensitivity (DMIS) "to explain the observed and reported experiences of individuals in intercultural encounters" (Jackson, 2010, p. 39). Bennett's theoretical framework uses the principles of ethnocentrism and ethnorelativism, where the former is rooted in the idea that one's own culture is central to all reality, and the latter is linked to an individual's acceptance of a variety of different standards and customs and one's ability to behave accordingly in different interpersonal settings (Bennett, 1993). Bennett (1993) theorizes that an individual moves through three ethnocentric states (denial, defense and minimization) and then through three ethnorelative stages (acceptance, adaptation and integration). With regard to study abroad situations, the model suggests that ethnorelative worldviews are indicators of intercultural competence (Kim 2001, 2005).

Neuliep (2006) argues that, "ethnocentrism is universal" (p. 33) and that someone's own cultural lens influences and, at times, distorts the perception of others. Furthermore, ethnocentrism is the foundation of patriotism and group loyalty, which is especially important when an in-group is under attack. At the same time, ethnocentrism can prevent members of an in-group from wanting to understand other cultures and "at high levels, ethnocentrism is an obstacle to effective intercultural communication" (p. 33). Neuliep and McCroskey (1997) suggest that ethnocentrism is not necessarily a sign of contempt or disapproval, but rather a descriptive notion. They developed the Generalized Ethnocentrism (GENE) scale to measure the level of ethnocentrism, which was used as part of this study.

\section{The Courses}

For the purpose of this study three different advertising-focused, short-term study abroad courses were examined including "International Media: Germany" (taught in 2008 and 2009) and "Visual Culture in Japan" (taught in 2010), all of which attracted mainly advertising students as well as some students from other majors. The three courses emphasized different areas of advertising as explained below. In addition, while students in both courses received cultural training and preparation prior to traveling, the course that focused on visual culture in Japan had a much more extensive preparation that stretched over eight weeks, as opposed to the Germany courses, which included a short but intensive one-week cultural preparation. The reason these three courses were selected for the purpose of this study was that they were in line with current trends in study abroad programs including 1) an increase in short-term programs, 2) faculty led programs as opposed to programs taught by the host country and 3) programs that address specific interests of students (advertising and visual culture). In addition, the Japan program is an interdisciplinary, teamtaught course as recommended by Burns (2003) and Rose and Ganahl (2000).

International Media: Germany. The course is typically taught during a three-week summer session which includes a week of cultural preparation followed by two weeks of travel to Berlin and Munich. The course was designed to give students exposure to German culture while also meeting with German advertising, public relations and marketing professionals. The first week of instruction consisted of a cultural profile of Germany including very basic language training and an overview of current issues in the German advertising and media industry. Once in Germany, the group followed a carefully developed itinerary that included important cultural sites as well as specific appointments with German media and advertising professionals in companies ranging from small to large advertising agencies (i.e., Scholz \& Friends, Fritzsch \& Mackat) to newspaper editors (i.e., Die Welt) and companies like the Volkswagen Group. Instead of simply "touring" the agencies and companies, the instructor set up creative challenges with German advertising agencies that students had to solve and then present to the agency. The course was set up entirely by the instructor who had strong connections to the German media industry. The course is focused on advertising practices and tends to attract mainly students majoring in advertising. However, news-editorial and broadcasting majors as well as students from other disciplines often enroll in the course as well. Each student had to submit an application packet consisting of transcripts, letters of recommendation and an essay explaining why he or she would benefit from the experience. Not every applicant was accepted into the program.

Japanese Visual Culture in Context. The Japanese Visual Culture course is an interdisciplinary course, team-taught by the author of this study who is an advertising educator, in conjunction with an art professor who specializes in visual literacy. The instructors applied for and received a course development grant, which made it possible for them to travel to Japan a year prior to offering the course in order to develop the program. 
Officially a general education course, it is crosslisted as an advertising and studio art course and tends to attract mainly advertising and art students. In addition, it is generally available to all students of the university and attracts several Japanese language students who are interested in visual literacy and advertising. Students had to submit an application packet consisting of transcripts, letters of recommendation and an essay explaining why they would benefit from the experience. Not every applicant was accepted into the program.

Students received an in-depth cultural preparation eight weeks prior to departure that included online discussions and occasional faceto-face meetings. The extensive preparation included basic Japanese language training, reading and discussing of books and films about Japanese visual literacy and advertising practices as well as an introduction to basic cultural communication models. The group then traveled to Kyoto where they experienced traditional Japanese culture including fine art and architecture. Students also participated in perceptual drawing exercises and stayed in a traditional Buddhist Zen Temple. The group spent the second week in Tokyo to experience modern Japanese culture, visit advertising agencies and reflect on their experiences using modern technology such as blogs, social and mobile media.

\section{Research Questions and Hypotheses}

Based on a thorough review of the literature, it is clear that researchers in fields other than advertising have measured the effectiveness of study abroad programs on students' worldviews (Pedersen, 2010; Jackson, 2008; Kambutu \& Nganga, 2008). However, no studies currently exist that focus on advertising-themed shortterm study abroad courses. Therefore, this study explores the effectiveness of short-term, advertising-focused study abroad programs on students' worldviews using a mixed methods design consisting of quantitative and qualitative data. The reason for collecting both types of data was to bring together the strengths of both forms of research to corroborate the results (Creswell \& Plano Clark, 2007).

The first research question focuses on the effect of short-term study abroad experiences on students' worldviews, as expressed by the level of ethnocentrism among participating students immediately before and after traveling to the other country.

$\mathrm{RQ}_{1}$ : What is the effect of advertisingfocused, short-term study abroad programs on students' worldviews as indicated by their level of ethnocentrism?
$\mathrm{H}_{1}$ : Students who participate in short-term, advertising-focused study abroad courses will self-report significantly lower levels of mean post-travel ethnocentrism as compared to pretrip mean ethnocentrism scores.

In addition, this study seeks to explore how short-term advertising-focused study abroad experiences affect students' perceived "global competence," which is one of the values and competencies required by ACEJMC accredited programs. Olsen and Kroeger (2001) defined a globally competent individual as someone who has sufficient substantive knowledge, perceptual understanding and intercultural communication skills to function in a globalized world. Donatelli et al. (2005) list general knowledge of the in-group and the out-group, fluency in a different language, cross-cultural empathy, openness and cognitive flexibility, tolerance for ambiguity, perceptual acuity, attentiveness to non-verbal messages and awareness of issues facing the global community as indicators of global competence. However, it is not clear if and how short-term, advertising-focused study abroad programs contribute to students' understanding of global competence.

$\mathrm{RQ}_{2}$ : How do students describe the characteristics of a globally competent individual before and after participating in an advertising-focused, short-term study abroad program?

The literature indicates that employers value intercultural communication skills and cultural experiences (Burn, 2003; Ganahl \& Rose, 2000). However, it is not clear how students perceive the benefits of study abroad experiences.

$\mathrm{RQ}_{3}$ : How do students describe the benefits of participating in an advertising-focused, shortterm study abroad program?

\section{Method}

This study used a mixed methods design to address the effectiveness of short-term, advertising-specific study abroad programs on students' worldviews. A triangulation mixed methods design was used in which different but complementary data were collected on the same topic (Creswell \& Plano Clark, 2007). In this study, Neuliep and McCroskey's (1997) GENE scale was used to measure the level of ethnocentrism displayed by students before and after participating in short-term, advertising-focused study abroad programs at a large Midwestern university (see Appendix A for GENE scale). Concurrent with this data, qualitative open-ended responses collected before and after participation explored students' descriptions of globally competent 
individuals as well as a reflection of the benefits of participating in a short-term, advertisingfocused study abroad program.

\section{Participants}

Participants were students from a large, research-intensive university in the Midwest. They participated in one of three advertisingfocused, short-term study abroad programs including two in Germany (in 2008 and 2009) and one in Japan (in 2010). To test the hypothesis that students will score lower on measures of ethnocentrism after having participated in an advertising-focused, short-term study abroad program, a convenience sample was selected that consisted of students who participated in one of three programs described earlier. The group studying international media in Germany in 2008 consisted of 15 students, 13 of whom completed the pre- and post-travel GENE scale. The group participating in the Germany program in 2009 consisted of 15 students, 14 of whom completed the pre- and post-travel GENE scale. The group studying Japanese visual culture in context in 2010 consisted of 18 students, 13 of whom completed the pre- and post-travel GENE scale. Overall, 40 students participated in this study. In addition to the obvious difference in travel destination, the courses differed in that the students who participated in the Japan course received more extensive cultural preparation prior to travel, including about eight weeks of online and faceto-face discussions. The Germany groups also received pre-travel cultural training, but it was limited to an intensive one-week preparation seminar.

\section{Design and Procedures}

In order to measure the effect of advertisingfocused study abroad students' level of ethnocentrism, Neuliep and McCroskey's (1997) GENE scale was administered twice as part of each program, before traveling to the other country (pre-travel) and immediately after returning to the United States (post-travel). The scale can be administered to any person regardless of cultural background. It contains 22 statements of feelings about one's culture as well as other cultures. Half of the statements are worded positively and the other half negatively. Fifteen of the items are used to measure ethnocentrism, while the other seven are distractors. According to Neuliep (2006), scores above 55 are considered high ethnocentrism. The questionnaire was administered on the plane to and from Germany/Japan.

The questionnaire also gave students an opportunity to articulate their expectations of each trip (pre-travel) and to reflect on the achievement of those expectations (post-travel) in the form of eight open-ended questions. The responses to the open-ended questions were used for the qualitative portion of this study. Data were analyzed using six steps of qualitative analysis and interpretation as suggested by Creswell (2003). First, the data were organized and prepared for analysis, which required the researcher to convert the hand-written answers from the pre- and posttravel questionnaires into one typed document. Second, the researcher read through all the data to obtain a general sense of the information and to reflect on the overall meaning. Third, the researcher started the coding process, which consisted of organizing the material into "chunks" and then labeling it with a term based on the language used by the participants. All of the data were coded by the author of the study. Fourth, the researcher then collapsed the initial codes into a small number of themes, each of which contained multiple perspectives. Each theme also was supported by direct quotes from participants. Fifth, the themes that emerged are described below as part of a narrative. Finally, the data were interpreted based on the researcher's own understanding of and experience with developing and leading study abroad programs. Meaning was created by comparing the findings with existing literature in different contexts as well as extant theories (Creswell, 2003).

\section{Results}

In order to answer the first research question about the level of ethnocentrism before and after participating in the study abroad program, Neuliep and McCroskey's (1997) GENE scale was administered. On a comparison of means between the pre- and post-travel scores of all participants, students displayed lower levels of ethnocentrism upon returning from their respective study abroad experiences. The combined mean pre-travel GENE score was 27.13 compared to a combined mean post-travel score of 24.18 , both of which are considered relatively low GENE scale scores, indicating low levels of ethnocentrism (Neuliep, 2006). A one-tailed t-test for dependent samples was conducted because the same sets of students were measured twice on the GENE scale (preand post-travel). The results were statistically significant $(t(39)=3.09, p<.01)$. The internal reliability of the GENE scale was found to be acceptable (Cronbach's alpha coefficient $=0.69$ ). Therefore, the results suggest that advertising-specific, short-term study abroad experiences may significantly decrease the level of ethnocentrism in students participating in these types of programs. 
In addition to the GENE scale, the pre- and post-travel questionnaire also included a set of eight open-ended questions that asked students to describe globally competent individuals ("world citizens"). In addition, students were asked to describe their expectations of the program (pre-travel) as well as a reflection of the benefits of participating in a short-term, advertising-focused study abroad program (post-travel) in their own words. After coding the responses to the open-ended questions, five themes emerged including an awareness of and appreciation for the out-group, an increased awareness of the in-group, the importance of communication, a positive effect on professional goals and opportunities for personal growth and inspiration to explore cultures in more depth.

The second research question focused on students' description of the characteristics of a globally competent individual before and after participating in an advertising-focused, shortterm study abroad program. In general, students' responses from the pre-travel questionnaire were very idealistic and included characteristics such as open-mindedness, being respectful and knowledgeable of other cultures, being willing to learn and tolerance. The responses were very similar on the post-travel questionnaire, but students reflected more deeply about them. The theme that emerged was an awareness of and appreciation for the out-group. As one student explained, "While being here in Germany I am now a foreigner and being on the other side of the fence increases my respect for global citizens and made me appreciate their effort to adapt to new customs and cultures. It makes you more tolerant of people from other countries because you know what it feels like to be in their shoes."

Students also recognized that while being part of the out-group is sometimes difficult, it brings new experiences. As one respondent said, "A global citizen is someone who respects all cultures and is willing to step outside their comfort zone to see that there is a whole other world out there." Another one added, "A global citizen should also develop an awareness of other cultures and seek to understand similarities/ differences without prejudice/stereotyping."

Students were asked to list any stereotypes they or other Americans may have about the culture and country they were traveling to on the pre-travel questionnaire. On the post-travel questionnaire they were asked to reflect on whether they found any of those stereotypes to be true. Most students acknowledged that their previously held stereotypical views did not describe the culture they were experiencing adequately. However, some students confirmed their stereotypical views upon returning to the U.S. As one student noted, "Germans tend to be a bit more rude than people in the U.S. Don't use 'excuse me' often." Some of the students traveling to Japan noted that the Japanese were indeed "quiet and group-oriented," which is what they had expected to see. Some students were able to interpret and correct their previous views. "My view of Germany before was a vision of Munich."

Another theme that emerged from a discussion about stereotypes was an increased awareness of the in-group. Whereas the pretravel guesses as to what kind of opinions other cultures may hold about Americans focused primarily on their physical appearance, the post-travel responses showed that students recognized how difficult it was for them to blend into another culture. They described themselves as obnoxious and loud, yet more friendly than the host culture. "I noticed that we were louder compared to most Germans and kind of stuck out in the way we acted and interacted with others." The same was true for the students who participated in the Japan program. "I was surprised to find out how quiet and respectful Japanese people are on the subway and other public transportation. People in Japan are concerned with each other's peace and harmony to a much greater extent than in the West." Another student reflected on how American culture can be perceived more broadly. "After being on this trip I have noticed some of the stereotypes Americans perpetuate. Not appreciating the culture of other countries and thinking there is only one way of doing things. There is a lack of respect for other cultures or even trying to understand them."

A third theme that emerged from the post-travel responses was the importance of communication. While some students had listed this characteristic on the pre-travel questionnaire as well, they provided more context after completing the program. "[A global citizen is] someone who respects other cultures and is willing to communicate with people from other cultures about the world and other people." Another student said, "I think a global citizen must have the openness to new experiences and the willingness to learn about other cultures. (S) he must learn to communicate in more than one language in order to have a broader worldview."

The purpose of the third research question was to determine how students described the benefits of participating in a short-term, advertising-focused study abroad program in their own words. Students' responses revealed that this kind of study abroad experience can have a positive effect on their professional 
goals and outlooks. As one student noted upon returning to the U.S., "My expectations were to gain knowledge about another culture and also about media in Germany. And I met these goals because I immersed myself in the culture and took notes at all media appointments. I heard a lot of good things to apply to my career." Another student realized how important it was to be aware of others' views of America. "Out of this experience, I gained an understanding of other views of America. I think it's good to know how other cultures view America because someday I may work for a global company." Another student addressed the applied learning opportunities in reference to a real-life advertising campaign concept the students worked on and then presented to an agency in Berlin. "My favorite thing was visiting Scholz \& Friends. I loved doing the challenge; it was such an amazing opportunity and learning experience. I realized how much passion I have for advertising and developing meaningful campaigns."

The other theme that emerged was that short-term study abroad experiences appear to provide opportunities for personal growth and inspiration to explore cultures in more depth. As one student from the Germany program explained, "I am so happy that I grasped this opportunity as I feel more rounded and cultured. Everyone needs this! I feel more alive and that there is just so much to do, see and learn. I grew individually and that is worth every penny spent. Best experience of my life." Other students reflected on the experience as the beginning to many more international experiences. "I expected to gain an understanding about how Germans perceive their history. I feel that I have gained some knowledge of this but there is much more to learn." Another student explained, "I feel that now that I've been here it will be easy to come back and I know I will someday." The students who participated in the Japan program had similar experiences. "I expected to learn about visual culture, become more independent, meet people and try new things. I feel like I got all that and more. I just had such an amazing experience and really grew as a person."

Two strategies were used to establish validity of the findings. The author used rich, thick descriptions to convey the findings, which has the potential to "give the discussion an element of shared experiences" (Creswell, 2003, p. 196). In addition, the author used peer debriefing to enhance the accuracy of the findings. Two peer debriefers were selected who reviewed and asked questions about the study to ensure that the account resonated with people other than the researcher, which it did (Creswell, 2003).

\section{Discussion}

The purpose of this study was to explore the effectiveness of advertising-focused, short-term study abroad programs on students' worldviews using a mixed methods approach. The study sought to answer three research questions. The first research question asked about the effectiveness of advertising-focused, shortterm study abroad programs in terms of the level of ethnocentrism among participating students before and after the program. The second research question asked students to describe global competence. The third research question focused on the benefits of short-term, advertising-focused study abroad experiences as perceived by students.

The quantitative results of this study are in line with existing research that shows that both long-term and short-term study abroad experiences positively affect students' intellectual change (Pedersen, 2010) and generally support Allport's (1954) intergroup contact theory which suggests that face-toface interaction, such as spending time in a different culture and interacting with members of the out-group, will decrease prejudice among group members. The current study suggests that short-term study abroad programs may reduce participating students' level of ethnocentrism as a result of participating in short-term, advertising-focused study abroad experiences. Overall, the mean scores of students' ethnocentrism scores pre- and posttravel decreased significantly. It should be noted that both the pre- and post-travel ethnocentrism means scores reported in this study indicate low intercultural communication apprehension (Neuliep, 2006), which means that students had relatively low levels of ethnocentrism before traveling. This finding might be the result of the general attitude of students pursuing study abroad opportunities. However, the fact that the mean score decreased significantly after participating in one of the programs suggests that even short-term stays abroad can contribute to students' intercultural communication skills as cultural competence and ethnocentrism are inversely related (Capell et al., 2008). Based on Bennett's (1993) Developmental Model of Intercultural Sensitivity (DMIS), it could be argued that students participating in this kind of study abroad experience achieved one or more states of ethnorelativism which includes acceptance, adaptation and integration. Kim's (2001, 2005) research suggests that ethnorelative worldviews are indicators of intercultural competence. 
The three themes that emerged as a result of the second research question confirm some of the existing literature and also provide additional insights. Allred et al. (2006) suggest that interculturality includes the process of experiencing an out-group situation and reflecting on the interactions of different groups. The post-travel reflections show that students have an awareness of, and appreciation for, the out-group, while also displaying an increased awareness of self (in-group).

Although most students recognized that previously held ideas of the country they were visiting only portrayed a very limited glimpse into that country's cultural fabric, it was interesting to see that some students confirmed these stereotypes after having participated in the study abroad experience. It is possible that these types of reflections are the result of negative interactions within the in-group, as suggested by Jackson (2008). Additional research needs to be conducted that explores in-group dynamics while being abroad and how they might affect ethnocentrism. The third theme that emerged dealt with the importance of communicating while abroad, which is consistent with intergroup contact theory (Allport, 1954). The results of this study indicate that students perceive language training to be an important component of even shortterm study abroad experiences. This is an important finding because it contradicts current trends in study abroad programs that no longer include foreign language training (Burn, 2003).

The two themes that emerged from the third research question add an important component to the existing literature on advertisingfocused study abroad programs. Students overwhelmingly indicated that advertisingfocused study abroad experiences had an overall positive effect on their professional goals and outlooks. This finding explores an important gap in the literature. Although several studies suggest that employers are looking for students with international communication skills (Burn, 2003; Ganahl \& Rose, 2000), none has explored students' perceived benefits from participating in these kinds of study abroad experiences. Finally, the fifth theme indicates that even short-term study abroad experiences can become personal growth opportunities and perhaps, more importantly, provide inspiration to explore other cultures in more depth. It should be noted here that several students who had joined one of the three study abroad programs described in this study decided to participate in long-term study abroad programs in subsequent years and/or opted to complete internships abroad.

\section{Limitations}

There are several limitations to this study. First, the sample in this study consisted of 40 students who participated in one of three different advertising-focused, study abroad programs sponsored by a single US university. It is possible that the relatively low pre-travel ethnocentrism mean score is an indicator of students' self-selection into study abroad students apply who are naturally interested in global issues and other cultures may apply for these programs as opposed to students who do not have the same level of interest and therefore would not consider studying abroad. Therefore, the study could have benefited from a control group that did not travel abroad.

Second, although the courses did not have a foreign language requirement, they both included some students with German/Japanese language skills who were able to communicate with individuals on the ground. As the literature indicates, the trend is toward short-term study abroad program without language components (Burn, 2003). However, it is also known that language is an important component of intercultural understanding (Neuliep, 2006), which may have influenced the lower pre- and post-travel score of the Japan group. It may also have influenced one of the qualitative themes that emerged regarding language skills.

Third, it should be noted that the sample consisted of students from three different study abroad programs. It is possible that the scores were influenced by students' backgrounds including gender, previous experience abroad, major and cultural aspects. Future studies should report the composition of the sample and relate the findings to those types of characteristics.

Fourth, another possible limitation may be the way the instrument was administered. Students were asked to complete the pre-travel and post-travel questionnaires on the plane to and from the country they were visiting, which may not have allowed them enough time to reflect on their experiences. Future studies may need to allow more time for reflection.

\section{Suggestions for Future Studies}

This study fills an important gap in the literature because it shows that even short-term study abroad experiences may significantly reduce the level of ethnocentrism among students, which is an important indicator of intercultural communication skills (Capell et al., 2006). However, additional research needs to be completed to explore and define the types of skills needed from the perspective of employers as well as students and faculty.

According to the current literature, many 
different types of study abroad programs exist (Burn, 2003). Because the trend toward shortterm, discipline-specific programs is relatively new, it is important to determine how to most effectively prepare students for these types of study abroad experiences. Research is needed that explores what type of "cultural training" should be offered to students, how long prior to the study abroad experience it should be offered and whether it has an impact on students' intercultural communication skills.

Also, as more and more advertising and public relations programs are trying to "internationalize" their curricula, it will be important to investigate the effectiveness of other types of international instruction on students' worldviews as reflected in their ethnocentrism score on the GENE scale. For example, some programs offer collaborative learning experiences with students from other universities in other countries, clients in other countries and/or international competitions (Hachtmann, 2011). Programs can use the GENE scale to measure students' levels of ethnocentrism before and after being exposed to global issues or solving a communication problem involving other cultures.

\section{References}

Accrediting Council on Education in Journalism and Mass Communications (2010). Journalism and Mass Communications Accreditation 2010-2011. Allport, G. W. (1954). The nature of prejudice. Reading, MA: Addison-Wesley. Alred, G., Byram, M. \& Fleming, M. (2006).
Education for intercultural citizenship: Concepts ad comparisons. Clevedon, UK: Multilingual Matters.

Anderson, P. H., Lawton, L., Rexeisen, R. J., \& Hubbard, A. C. (2006). Short-term study abroad and intercultural sensitivity: A pilot study. International Journal of Intercultural Relations, 30(4), 457-469. doi:10.1016/j.ijintrel.2005.10.004

Bennett, J. M. (1993). Cultural marginality: Identity issues of intercultural training, in R. M. Paige (ed.), Education for the intercultural experience (pp. 109-36). Yarmouth, ME: Intercultural Press.

Burn, B. (2003). Study Abroad. In J. W. Guthrie (Ed.) Encyclopedia of Education, (Vol. 7). (2 ${ }^{\text {nd }}$ ed., pp. 2394-2396)

New York: Macmillan Reference USA Retrieved June 28, 2011, from Gale Virtual Reference Library via Gale: http://0-go. galegroup.com.library.unl.edu/ps/start. do? $p=$ GVRL\&u $=$ linc 74325

Capell, J., Dean, E., \& Veenstra, G. (2008). The relationship between cultural competence and ethnocentrism of health care professionals. Journal of Transcultural Nursing, 19(2), 121-125.

Creswell, J. W. \& Plano Clark, V. L. (2007). Designing and conducting mixed methods research. Thousand Oaks, Calif.: Sage Publications.

Creswell, John W. (2003). Research design. Thousand Oaks, Calif:: Sage Publications.

Datamonitor (2010). Global advertising industry profile. Reference Code: 0199-0420 Publication Date: July 2010.

Dickerson, M. A. (2005). One example of a

\section{Appendix A \\ Neuliep \& McCroskey's GENE Scale (1997)}

\begin{tabular}{|l|l|l|}
\hline \multicolumn{3}{|c|}{ Please mark the following 22 statements according to the following scale: } \\
\hline "5" if you strongly agree; "4" if you agree; "3" if you are undecided; "2" if you disagree; "1" if you strongly disagree \\
\hline 1. & & Most other cultures are backward compared to my culture. \\
\hline 2. & & My culture should be the role model for other cultures. \\
\hline 3. & & People from other cultures act strange when they come to my culture. \\
\hline 4. & & Lifestyles in other cultures are just as valid as those in my culture. \\
\hline 5. & & Other cultures should try to be more like my culture. \\
\hline 6. & & I'm not interested in the values and customs of other cultures. \\
\hline 7. & & People in my culture could learn a lot from people in other cultures. \\
\hline 8. & & Most people from other cultures just don't know what's good for them. \\
\hline 9. & & I respect the values and customs of other cultures. \\
\hline
\end{tabular}


successful public relations program.

Public Relations Quarterly, 50(3), 18-22.

Donatelli, L., Yngve, K., Miller, M. \& Ellis, J. (2005). Technology and education abroad, in J. L. Brockington, W. W. Hoffa, and P.C. Martin (eds.), NAFSA's Guide to Education Abroad for Advisors and Administrators (pp. 129-150). Washington, DC: NAFSA: Association of International Educators.

Dunn, S. Watson (1994). Early days of international advertising education in the U.S. Journal of Advertising, 23(1), 111-113.

Ganahl, D. \& Rose, P. (2000). Invited commentary, Journal of Advertising Education, 4(1), 4-6.

Hachtmann, F. (2011). International advertising education: A research agenda. Association for Education in Journalism and Mass Communications 2011 Annual Convention.

Heiman, S. (2001). Invited commentary, Journal of Advertising Education, 5(2), 5-8.

International Advertising Association (2011). IAA: Inspiring excellence in communications worldwide. About IAA. Retrieved February 15, 2011 from http://www.iaaglobal.org/\#aboutiaa.

Jackson, J. (2008). Language, identity, and study abroad: Sociocultural perspectives. London: Equinox.

Jackson, J. (2010). Intercultural journeys: From study abroad to residence abroad. Houndmills, UK: Palgrave MacMillan.

Kim, Y. Y. (2001). Becoming intercultural: An integrative theory of communication and cross-cultural adaptation. Thousand Oaks, CA: Sage Publications.

Kim, Y. Y. (2005). Adapting to a new culture: An integrative communication theory, in W. Gudykunst (ed.), Theorizing about intercultural communication (pp. 375-400). Thousand Oaks, CA: Sage Publications.

Lee, W., Chen, C. \& Katz, H. (1997). International advertising education in the United States: A preliminary study and evaluation. International Journal of Advertising, 16(1), 1-26.

Miracle, G. E. (2008). Personal experiences of veteran advertising educators: Some of my favorite experiences in international advertising education. In B. I. Ross \& J. I. Richards (eds.), A century of advertising education (177-186). American Academy of Advertising.

Neuliep, J. W. (2006). Intercultural communication: A contextual approach, $3^{\text {rd }}$ ed.,
Thousand Oaks, CA: Sage Publications. Neuliep, J. W. \& McCroskey, J. C. (1997). The development of a U.S. and generalized ethnocentrism scale. Communication Research Reports, 14, 385-398.

Olsen, C. L. \& Kroeger, K. R. (2001). Global competency and intercultural sensitivity. Journal of Studies in International Education, 5(2), 116-37.

Pedersen, P. J. (2010). Assessing intercultural effectiveness outcomes in a year-long study abroad program. International Journal of Intercultural Relations, 34(1), 70-80. doi:10.1016/j.ijintrel.2009.09.003

Rose, P. B. \& Miller, D.A. (1993). Integrated communications and practitioners' perceived needs. Journalism Educator, 48(1), 20-27.

Steeves, H. L. (2006). Experiencing international communication: An internship program in Ghana, West Africa. Journalism and Mass Communication Educator, 60(4), 360-375.

Williamson, W. (2010). 7 Signs of Successful Study-Abroad Programs. Chronicle of Higher Education, 56(41), A27-A27. 
Copyright of Journal of Advertising Education is the property of Journal of Advertising Education and its content may not be copied or emailed to multiple sites or posted to a listserv without the copyright holder's express written permission. However, users may print, download, or email articles for individual use. 